\title{
Colonialism and the Post- Colonial Nigeria: Complexities and Contradictions 1960 - 2015: A Post -Development Perspective
}

\author{
${ }^{1}$ Imoh Imoh -Itah, ${ }^{2}$ Luke Amadi ${ }^{3}$ Roger Akpan \\ ${ }^{1}$ Department of Public Administration, Akwa Ibom State University, Obio Akpa Campus \\ ${ }^{2,3}$ Department of Political Science and Administrative Studies, University of Port Harcourt, Nigeria.
}

\begin{abstract}
This paper re-engages in the post-colonial debate using a post-development theoretical framework to interrogate the post-colonial Nigeria in relation to economic development. It argues that the colonial state contrived an incongruous, entity called Nigeria and in particular, a derisive developmentalism. A conceptualization of some of the salient issues associated with these complexities in the post-colonial Nigeria is revisited and argued as posing enormous challenges to the future of Nigeria's development notably persistent ethno-religious crisis, perverse rise in ethnic minority agitation and struggle for the control of the oil economy in the Niger Delta, the Boko Haram insurgency and terrorism in the northeast, structural inequality, fiscal federalism, census figure, public corruption etc. The paper integrates Nigeria's colonial history in the larger picture of her political and economic (under)development and in the process suggests new explanation for underdevelopment and structural inequality in Nigeria linked to colonial legacy and makes some policy recommendations.
\end{abstract}

Keywords: Post colonialism, Identity, Governance, Development ,Nigeria

\section{INTRODUCTION}

The contemporary development plight of Nigeria at post oil economy and resurgent local crisis from Boko Haram terrorism in the northeast, cattle rustling, Fulani herdsmen and rural violence in the north central , the Shiite sectarian crisis in the northwest, the resurgent clamor for self -determination by the Indigenous Peoplese of Biafra,(IPOB) in about four decades after the Nigeria/Biafra civil war (19671970), the re-emergence of militant groups such as the Niger Delta notably the Niger Delta Avengers, and the Red Egbesu Water Lions at post amnesty to the Niger Delta militants in 2005 etc, are among the novel trends in contemporary post - colonial Nigeria.

Although since independence in 1960 a number of thorny issues remain contestable such as the ethnic minority question, inequitable revenue allocation formula, asymmetrical state structure, lack of true federalism, inability to evolve exact census figures, ethno-religious crisis, public corruption etc. In particular, the fears of the ethnic minority groups resulted in setting up of the Willink's Minority commission in 1958.

However most of these challenges re-emerge in everyday lives of Nigerians as threats to corporate existence of Nigeria. All these point to discernible complexities and contradictions of the post colonial Nigeria in five decades of political independence and almost two decades of nascent democracy. In the past few years, post- colonial studies and similar anti -imperialist theoretical explorations of Afrocentric discourse seem to have been relegated in contemporary development discourse. A novel criticalre-engagement is expedient to either de-redicalize or de-hegemonize the post-colonial agenda in relation to the contemporary global international capitalist asymmetry and post oil economy in Nigeria.

The colonial state was all interventionist, repressive and exploitative (Coleman, 1958; Ake, 1981; 1996; Ekekwe, 1986; Young, 1994). Based upon post-colonial theoretical debates and narratives, the inevitability of exploring the post -colonial Nigeria becomes expedient as idyllic history that draws upon true identity and ethos of Nigeria is increasingly interrogated (Ekeh,1975).

The preservation of Nigeria's cultural and historical artifact is sought for, in an attempt to recolonize Nigeria and unveil the dark side of bias colonial history, and also identify its effects on development 
of Nigeria as well as possible positive impacts, exploring the obvious fact that creating a historical imagery of a people is not built upon the relegation and destruction of the peoples' culture or decimation of their values and imposition of alien identity and practices.

Contriving the political history of a people should not be reprehensible, fictitious, vague and indistinct. The colonial history of Nigeria and its accompanied relics deserve immediate revisiting, as such narratives arguably do not recognize or uphold true depictions of Nigeria. It should be interrogated within the framework of post- developmentalism encompassing challenges such as the contested dual identity as Peter Ekeh (1975) provides the conflicting identity between the colonial urban and the rural African in analyzing the dilemma of "two publics". the problems of evolving true federalism, exact census figures, equal state structure etc.

The post -colonial structures whether deployed positively or negatively, undermine the fact that Nigeria has a rich cultural heritage, values, norms and ethics which constitute a shared socio-cultural heritage handed down generationally and often deployed as guiding ethos and mode of behavior to articulate morality in the society. The symbolic relationship between culture, history and identity is a striking feature of rich cultural heritage . Colonial history neither upholds nor draws from narratives of past Nigerian historical depictions, rather attempts to destroy the African culture and foster alien orientation. According to Ake (1996:12), Colonialism in Africa was markedly different from the colonial experiences of the Americas, Europe, and Asia. He argues that, it was unusually statist, stating thatthe colonial state redistributed land and determined who should produce what and how. That it often deployed forced labor, imposed taxes and a break up of traditional authority and social relations of production resulting in proletarianization.

Recent concern to re-engage in the postcolonial debate is to demonstrate the re-occurring contradictions and logic of colonial legacy. The most recent perhaps was Nigeria's 2014 centenary celebration as a colonial invention. The "historic" centenary celebration began across the country as the year 2014 approached which undoubtedly re-invoked neocolonial and neo imperialistic memor.

Proponents argue that Nigeria was one hundred years in 2014 with prospects for development (FGN,2014). Critical postulations on the contrary seek to interrogate the content and structure of the centenary. Centenary of military dictatorship, coups and counter coups, thirty months civil war, ethnic mistrust and crisis, religious fundamentalism and terrorism, poverty, structural inequality, corruption, false identity and false consciousness, perverse rise of civil society agitation etc. This points to the question of whether Nigeria is actually hundred or the entity amalgamated by the British in 1914.

This paper seeks to substantially examine salient demonstrate several contradictions and complexities surrounding the post- colonial governance in Nigeria as inherited structures from the colonial state. These issues which over the decades of political independence have not been given adequate scholarly attention reappear in everyday life of Nigerians and constitute a problematique of this debate which needs to be redirected for a novel value re-orientation, new nationalism, recolonization and remoralization of the political space.

There are important policy connections in re-evaluating the post- colonial state. First is to re-awaken the intellectual curiosity of post-colonial intelligentsia, and resist further in-roads of neo-colonial and neo- imperial theatricals such as the resurgent culture imperialism propagated by the Western globalization, same sex marriage legalization in the United States, resurgent strange diseases such as HIV/AIDS, Ebola Virus, Zika virus etc.

Similarly to redefine and mediate on possible interface between colonialism and underdevelopment, an appreciation of which is essential for the economic liberation of Nigeria. The problems of colonial exploitation which undermined economic transformation and development of Nigeria and indeed Africa is critical. These connections which continue to affect Nigerians and their perception of themselves as inferior, less productive and non- proactive to chart a self -reliant development cause is riddled with convoluted mental relapse fostered by the colonial state within the psycho-social remits of "colonial mentality". This has perpetrated individual and institutional dependency(Amadi,2012) ,which continues to undermine self- reliant development of Nigeria as post - colonial development strategies have been naïve, uncritical and riddled with fractured Western subjectivism and conditionality. 
The article argues for the need to present for consideration the salient elements of the overall "colonialism and underdevelopment" picture in post-colonial Nigeria. In doing this,the article seeks to generate novel research and policy agenda for the 21 st century development paradigm for Nigeria namely post oil homegrown economic diversification which is open to further debates in particular, to fashion a mode of understanding of the post-colonial debate in post development discourse.

This article, attempts to answer some of the salient questions that surrounds repeated failures of the post -colonial Nigerian state and explores the logic of colonial legacy to demonstrate re-occurring developmental failures attributed to inability to interrogate the status quo by doing three things. First, it identifies some of the connections between bias colonial history of Nigeria and underdevelopment such as the acclaimed colonial development plans - 1945 to 1956 and 1956 to 1960 to demonstrate failures of the colonial state which has been important in appraising post-developmentalist debate in the neo liberal order.In the particular field of development history there is need to provide theoretical framework for understanding the connections between colonialism and underdevelopment.

Secondly, it provides salient debates and theoretical issues raised by the logic of colonial legacy, what it means and how it has been a clog to the Nigerian self -perception, economic emancipation and development and thirdly suggests what the developmental significance of re-colonizing Nigeria means, for political, economic and social liberation of Nigeria as well as the wider African society.

While no attempt is made to provide an exhaustive account, laudatory and derogatory implications of colonialism is attempted to avoid a one sided debate. However significant evidence is provided to demonstrate how the negative commemorations outweighed the positive. The paper seeks to provide both theoretical and conceptual insights into the impasse that confronts post -colonial Nigerian State. A novel theoretical argument which merits further research is made as the paper remains optimistic that this overview highlights some of the relevant issues and acquaints both the newcomer, researchers and policy makers with the nature and range of post-colonial development failures which are at issue in interrogating part (not all)of the core economic development problems of Nigeria.

\section{THEORETICAL FRAMEWORK}

Just as there is no one post -colonial theory, there is neither one development theory. Neo Marxist post- colonial scholars explore the diversity of approaches and varying connections between colonialism and development. These debates reflect not only different development perspectives such as post-colonial theory, dependency, modernization, etc, they also reflect different understandings of the nature, and solution to, pressing development problems (Ake,1996). So, it is an open question of how colonialism negatively affects development which needs to be properly re-examined. Although this is not a new debate, what distinctively stands this proposition out is its emphasis on post developmental leanings in exploring the post- colonial era between 1960 to the 1990s to understand possible changes and impacts of the Western colonizing mission on poverty, ethnic mistrust, exploitation and underdevelopment especially in hundred years of acclaimed configuration of Nigeria by the British and since the return of Western democracy since 1999.

In exploring the complexity of the colonial history, our aim is to substantially explore, interrogate and understand how developmentalism has fared in post- colonial Nigeria. Hence a postdevelopmental framework. Amadi, etal;(2015) contend that post -developmentalism seeks for more ethical and equitable guidelines in pursuit of development project. It is a conscious interrogation and break away from the neo liberal development project riddled with inequality. Esteva (1992) demonstrates the contradictory images of "development"as a reminder of what it is not and in particular "an undesirable, undignified condition".

Post developmentalism is associated with the interrogation and assessment of Western development project. Pieterse (2010) recounts decades of failure of the western development project as it has not measured up to expectation particularly in Africa, parts of Latin America and South Asia. He contends that "the universalist claims of neoclassical economics", and similar development policies as the structural adjustment, have undermined the basis of development studies.

What one takes to be a genuine development will depend largely on how one conceptualizes issues such as the effects of colonial exploitation, Western imperialism, global inequality and similar development history of nations especially the colonized and exploited periphery societies. What most 
development scholars do hold in common, however, is the view that there are important connections between the domination of the poor colonized societies by the colonizing advanced capitalist societies perpetuated with the twin exploitations of neo colonialism and neo imperialism(Amadi,2012). What the implications of these alleged connections is and which, if any, are accurate descriptions of the nature and root sources of the dominations of the poor societies and nature of underdevelopment is largely what post development debate seeks to re-engage.

\section{CONCEPTUAL ISSUES}

A conceptual edge is important to understand dynamics of colonialism and underdevelopment nexus. Colonialism remains important in Nigerian development discourse as the various historical, conceptual, and empirical debates provide strong link with colonialism and development and create plausible insights in understanding the development of underdevelopment. They also inform the need for alternative development policy. A radical anti-colonial development framework would address the economic failures and dissociate from the Western imperialistic strategies (Frank, 1968).

Although the number of scholarly articles, and books on colonialism blossomed since the 20th century, this paper is a revised elucidation of the postcolonial debate in era of post developmentalism, neo liberal order and globalization. In post- colonial debates, Ake(1996) acknowledges some changes on the composition of the state managers as a result of political independence but maintained that the character of the state increasingly remained as it has been since the colonial period. He contends that it remained totalistic, an apparatus of violence with narrow social base, relied on compulsion rather than on authority.

Onimode(1983) locates post-colonial conceptual links within the crisis of underdevelopment of Africa and contends that such crisis is basically structural and historical. Amadi(2012a)reinforces this "structural and historical" conceptualization of underdevelopment and follows Topik,(2002)who contends that many social scientists have argued that, ultimately, causal links between colonial plunder and exploitation are replete in conceptual structures of underdevelopment particularly in the Third World intellectual tradition.

One account situates the conceptual basis of colonialism in modernization (Rostow,1960). Such debates have attracted increasing criticism from the Third World scholars. Particularly among the post-modernization the orists (Ferguson, 2006) and the post structural perspectives (Wesintein, 2008).More radical critique is reflective of the dependency school discernible among the Latin American scholarship, (Furtado, 1964; Wallestein, 1976; Frank, 1970 ;).

Pieterse (2010) shows that in the social science the dependency theory greatly influenced development theory including debates on the world system analysis. This is particularly important in the understanding of systemic global symmetry(Wllestein,1976;Amadi,2012).Much of the corresponding conceptual explorations linked largely to the dependency debate have been explored. For instance Amadi(2012:2)recounts that two dependency traditions are discernible to understand Western imperialism namely " the Marxist influenced by Paul Baran and Paul Sweezy, and developed by André Gunder Frank, others include Samir Amin, Arghiri Emmanuel, The otônio dos Santos, and Aníbal Quijano.Amadi (2012)argues that the dependency tradition is associated with the Structuralist school that builds on the work of Raúl Prebisch, Celso Furtado and Aníbal Pinto at the Economic Commission for Latin America and the Caribbean (ECLAC).He re-echoes that the structuralist approach is reinforced in the works of Fernando Henrique Cardoso and Enzo Faletto and perspectives from Peter Evans, Osvaldo Sunkel and Maria da Conceição Tavares.

Chakrabarty, (1992) interrogates "Europe's acquisition of the adjective modern for itself"as fundamental basis of European imperialism. Similarly, Ashis Nandy (1983) argues that colonialism helped to transform the concept of the modern West from a geographical and temporal to psychological category and points out that "West is now everywhere, within the West and outside, in structures and in minds".

Some debates in the literature have attempted to debunk blaming colonialism and imperialism as entirely responsible for Africa's underdevelopment. According to Okowa(1995:35 )blaming the imperialists serves as"an emotional balm but does not help us at all. Why are we having competent, development conscious leaders in, for example, South East Asia where American and Japanese imperialism are concentrated"? 
In Nigeria a number of literature trace the historical and causal connections of colonialism to economic imperialism as a dominant mode of patterns of development of underdevelopment (Ekeh,1975;Nnoli,1978;Ake,1981,1996; Onimode,1988;Ekekwe,1986;).Peter Ekeh (1975) for shadows the historical role played by rationalism and important conceptual dualisms. Mamdani (1996) follows Ekeh's perspectives and posits that political power divergence in Africa is an attribute of Africa's colonial experience which led to two key systems of power under a single authority namely; urban and rural based.

Debates on colonialism and dislodgement of the Nigeria's social formation is well documented(Ak e,1985;Ekekwe,1986). The Colonial state destroyed the idyllic natural economy and imposed extraneous mode of behavior on the colony through imposition of cash crops production, taxation, imposition of finished imported products on the Africans(Ekekwe,1986;Ake,1996).

Similarly, there are cultural changes that occurred during the colonial era as Nigerian value system were eroded (Amadi and Agena,2014). On the economic front was economic exploitation(Coleman,1958;Onimode,1988).The contention is that the colonial experience has been oppressive and repressive represented in most radical neo Marxist scholarship(Onimode,19 88;Ake,1981;1996;Ekekwe,1986,)And that the colonialists pursued an entirely different colonial agenda in Africa (Rodney,1972;Amin,1973;Ake,1996; Amin,1997;).

This remarkable difference is revealed in the various consciousness and consequences the postcolonial state has on Africans. It is rooted in the paradigm of development of underdevelopment (Amin,1973;Rodney,1972;Wallestern,1976)and dependency (Dos Santos,1970;Amadi,2012). Such mode of exploitation are critically linked to the dominant Western Economic appropriation (Amin, 1973,1997).

Beyond material resource plunder are the nexus with human resource exploitation replicated in slavery and slave trade as prelude to formal colonialism. Rodney (1972)argues that the quantification of human resources sold into slavery is a measure of the effect of social violence rather than trade in any sense of the word.

Some conceptual explorations draw on some of the historical connections between colonialism and development. According to Young (1994)the concept of development from these antecedents ,first became a consciously articulated part of state ideology. In its French version, labeled misen valeur, the doctrine received resonant statement from Albert Sarraut, colonial minister from 1920 to 1924 and a former Governor -General of Indochina. Despite the claim of the colonial state to development, Young (1994)observes that the 1929 British colonial Development and Welfare Act, and its alleged development promises were not matched by its practical impact owing to the anemic funding levels .Such failed ideology was replicated in the acclaimed colonial development plans in Nigeria such as the so called Ten Year Plan of Development and Welfare for Nigeria 1946-1956, which was terminated in 1954, followed by the second 1955-1960 Plan, third and fourth plans. The colonial and post -colonial development plans were riddled with failures as it did not understand the core development problems of Nigeria(Nnoli,1978).

Colonialism further locates the conceptual link between the "metropolitan and external audience". Thus, a link was explicitly created between the imperial office and the colonial office under the administration of the colonial Governor General in the metaphors and models of colonial administration. Young(1994) observed that this reformulated doctrine of state was still primarily directed toward the metropolitan and external audience but no longer exclusively so. However, Young(1994:34)recounts that the sense of new stirrings in civil society began to percolate in to the official consciousness. In Egypt the shock of the 1999 Cairo riots brought to an early end to the end the brief period of incorporation into an empire. The first nationalist agitation in Tunisia, the 1925uprising in Syria. The Aba women riots in Eastern Nigeria in 1929, the Mau- Mau rebellion in 1957 among several colonial uprisings.

The literature and discourse on negative commemoration of colonialism continues to gather momentum in leaps and bounds and will continue to grow as African states are poorer today than they were at the advent of colonialism worsened by the negative effects of the colonial legacy such as repeated inter -state crisis all over Africa, coups and counter coups at the resurgence of democracy since the 1990s which points to democracy recession in Africa. There are issues of poor colonial boundary and demarcations as primary triggers of African conflicts (Amadi, Imoh-Itah and Roger,2015)which often implicates the post-colonial state. The colonial land use and minerals acts 
and similar natural resource extraction statutes remain at issue in post- colonial resource conflicts. Largely involving the Western imperialistic multinational corporations on one hand and the exploited oil bearing communities on the other as in the case of the Niger Delta region. This draws from economic exploitation rather than developmental motives and glaringly reinforces the dark side of neo-colonialism, supportive of the palpable contention that the founding ideals of Western colonialism is built upon the economic ambitions of Britain which repeatedly affects Nigeria's economic transformation and poor rethinking.

There is need for a new nation-building by producing alternative options of economic transformation, notably within the framework of post oil home grown economic diversification aimed at novel indigenous strategies. Ironically these have been minimally internalized in the development agenda of post-colonial Nigeria.

On the contrary, negative colonial legacies such as corruption, ethnic hostility and intolerance have eaten deep into the Nigerian social fabrics and will remain a substantial mode of public behavior for a long time. A related account expands on the destruction of natural economy, imposition of cash crop production and export trade in local commodities which became the dominant feature of the colonial economy by linking colonialism with broader illumination of commodity expropriation and .1983 dislodging conceptual frameworks (Onimode,1988).

Appeals to such theoretical and empirical data are aimed at demonstrating the connections between colonialism and underdevelopment and to inject critical motivations on the concerns expressed on post colonialism and development crisis. Others suggest confronting colonialism and Western imperialism and debunk blaming Africa's poverty entirely on colonialism. For instance, Okowa (1995) argues that Ethiopia which is the poorest country in Africa was not formally colonized. Whether from positive or negative perspectives, colonialism constitutes an instrument of underdevelopment and exploitation deployed to articulate the Western colonizing mission.

For our purpose, this article argues that colonialism is the pattern of relationship and the connections between the domination and exploitation of one country by the other as one occupies the other and imposes its whims and caprices. The article contends that colonialism has an economic motive though a complex process. Much of this debate within the post- colonial state is explored from the post developmental lens, which is a perspective that critically assesses how the Western developmental project has fared in strict economic development terms in the periphery societies. The paper attempts some pervasive challenges of the post-colonial Nigeria such as -inequality, poverty, exploitation, corruption, ethnic intolerance, quasi federal arrangement, poor fiscal federalism, which require novel policy re-engagement.

\section{Post- Colonial State and Complexities of Governance}

The contemporary complexities of the post-colonial Nigerian state have several dimensions. In Particular; it lies in the oppressive character of the colonial state. This is by no means exhaustive here .Young (1994) contends that state has been defined from the Eurocentric conception which necessitated the persistent usurpation of the colonized territory by the colonial state. The mode of colonial plunder and exploitation have resulted in economic domination(Rodney, 1972). Before the partition of Africa and "formal" colonialism , slavery and slave trade were among the instruments of European oppression which misrepresented and humiliated Nigerians( Africans) and indeed the black race.The European colonial historians rarely re-examine the barbaric conquest of African empires and kingdoms, subjugation and enslavement of the people, what Maulana Karenga termed,"the holocaust of enslavement" and contends that slavery is a morally monstrous act of genocide that is not only against the people themselves, but also a crime against humanity. Ryan (2002) had asked for possible payment of reparation by Europe to Africa for colonialism and slavery. The Europeans contrived selfserving economic usurpation with blatant use of force, access and control of the slave economy with the legitimization of slave trade and erection of slave ports. The Atlantic slave traders included: the British, Spanish Portuguese, French, and the Dutch Empire. They created stations across African coast to buy or capture slaves from home African leaders.

In 1861 Lagos became a British colony and centre for expansion of British political influence and vested economic interest, which blossomed with aggressive military expansion at the end of the 19th century. In 1900, the north was declared a protectorate followed by the amalgamation of northern and southern protectorates in 1914. 


\section{Development Perspective}

The Dual Mandate provided another related account of derisive developmentalism and colonial bias, as the first published book that documents the motives of the colonizing mission in Africa following the partition of Africa as it posits that 'the partition of Africa was as we all recognize is due primarily to the economic necessity of increasing the supplies of raw materials and food to meet the needs of the industrialized nations of Europe'(Lugard,1965). Important accounts of the ongoing debate locates colonial state within the confines of constitutional provisions imposed on Nigerians which particularly discriminated and dissociated Nigerians from their developmental needs such as the Clifford's constitution of 1922, the Richards constitution of 1946,the Macpherson's constitution of 1951 ,the Littleton's constitution of 1954 all reflected the interest of the British colonizing mission. For instance, the elective principle of the 1922 constitution was elitist and had a restricted franchise as the four seats it provided for Africans were allocated only to British protected persons with an annual gross income of two pounds. The legislative body it established legislated in the interest of the imperial office in London and not for the welfare and interest of Nigerians. Such as the land use act, the minerals act ceded all natural resources to the imperial office ( James Coleman,1958).

Such inadequacies demonstrate the patterns of administration inherited by the post-colonial state. The colonial state maintained its statist policy, divide and conquer strategy that left behind a legacy of disunity in the Nigerian political space. The Richards constitution introduced regionalism which injected ethnic consciousness in the fabrics of Nigerian polity as it divided Nigeria along regional lines. Northern, Western and Eastern. This gave rise to the ethnic coloration of most post 1946 political parties in Nigeria which increasingly operated along ethnic lines to gain or reassert political legitimacy. This primarily resulted in the logic of "northern primacy" in Nigerian body politic as the motto of the first political party in the north namely; the Northern Peoples' Congress(NPC)-which was "One north One people" suggests. Thus, national cohesion, socio- economic and political legitimacy, were built along regional or ethnic lines.

In the Western region, Nigeria's foremost nationalist leader Dr Nnamdi Azikiwe whose political sophistry and cosmopolitan brand of politics endeared him to Nigerians was reduced to an ethnic leader following the ethnic chauvinism of Chief Obafemi Awolowo who capitalized on the "nonindigene strategy" to conscientize his Yoruba kinsmen against a non-Yoruba (Dr Azikiwe)"allegedly controlling the Western Nigerian cocoa economy" hence his removal from the Western region house(Achebe,1983).Dr Azikiwe returned to Enugu when he lost the seat in the Western House and displaced Professor Eyo Ita an Efik in Eastern regional House in Enugu which did not go down well with the eastern minority areas of non -Igbo extraction (Nnoli,1978;Achebe,1983).

Among common citizens, the popular notion of ethnic attachment has calcified and may not easily fritter away in the psychology and political perception of an average Nigerian. Nostalgia for colonialism varies along intellectual, political, socio-cultural and even gender lines.

The politics of state creation and structural inequality was inherited from the colonial state. After the incongruent amalgamation of 1914,the separatist agitation began (Tamuno,1970). Minority agitations and fears that led to the setting up of the Willink's minority Commission of 1958, remains strong in contemporary Nigeria. The Niger Delta minority agitations was given a teeth with the twelve days Isaac Adako Boro led insurrection against the Nigerian state in 1966 from the Ijaw ethnic Minority extraction, replicated in the resurgent militancy and hostage taking in the Niger Delta since nascent democracy in 1999. Obi (2001) made some remarkable observations in the oil minority groups that points to persistent "oil minority identity".

Similar structural asymmetry was inherited by the post-colonial state and replicated in patterns of state creation in Nigeria which was largely not informed by economic motives. The Mid West was created to vitiate the political fame of the NCNC in 1963, the states created by General Gowon was informed by the quest to reduce the power of the secessionist Biafra in 1968, this trend followed the patterns of states created by the military. Although General Murtala's nineteen states structure had a fair spread, it did not give greater consideration to a number of factors. For instance, the northern and eastern minority areas remained coalesced, also the Igbo areas had only two states. The General Babangida state creation was largely informed by political choices. For instance Asaba the home town of his wife was made the capital of Delta state rather than Warri a more cosmopolitan city.

Significantly, the Abacha administration created additional states that arguably emerged seemingly on the basis of marginalization and economic backwardness such as, Ebonyi, Bayelsa, Nasarawa, 
Zamfara, Gombe, Ekiti. Beyond these, several states in Nigeria are of unequal sizes. Federalism introduced by the Richards constitution did not reflect true federal system. Such asymmetrical federal arrangement subsisted in the post- colonial state as Nigeria has not evolved effective fiscal federalism which is one of the core development problems of contemporary Nigeria federalism (Egwu,2003;Elaigwu,2005)The indirect rule adopted by the colonial administration was a system of divide and rule which had different agenda for the northern and southern Nigeria. Whereas in the north it made laws through proclamation, in the South, it legislated. Indirect rule was a cheap pattern of administration and used local institutions and personnel to administer and further created a novel elite that were modeled along colonial lines which served the interest of the British and saved the huge economic and political cost of running effective and efficient government. These elite remained a problem to the post- colonial state. Abdul Babu(1981) underscores this scenario this way; "For now it is the privileged who exclusively enjoy state power and by their alliance with foreign capital enrich themselves at the expense of the underprivileged. Leaders in Africa, reluctant for obvious reasons to accept this new development, have plunged the continent into unprecedented social turmoil. No continent in such a short span of time since the attainment of independence has witnessed so many social upheavals with so few, if any, positive social results"(p.4). Corruption and economic plunder are sets of colonial legacies. There is not one policy on reparation of colonial plunder, given the poverty of the colonized periphery societies necessitated by exploitation. This finds plausible explanation within corruption dynamics. Colonialism is the nexus of formal corruption (Nnoli,1978;Amadi and Ekekwe,2014)Colonial conquest was another substantial strategy of decimation of Nigerian traditional kingdoms. Ake(1996)argues that economic and political power were the central calculus of the colonial politics. Thus power was everything and was sought by all means. The decimation of Nigerian historical and cultural artifacts was discernible. Eurocentric claim is that Africa has no history or culture. While on the contrary Africa had well developed history and system of governance., For instance Nigerian historian Onwubiko (1987)observes that between the 11 th century before European conquest to the late 19th century, the entity presently known as Nigeria was home to well socialized, sophisticated and influential societies. Such as the acephalous and republican Igbo of the south eastern Nigeria,the Igbo-Ukwu artefacts, the Nri myth, the Yoruba citystates/ kingdoms of Ife, Oyo, and Ijebu in southwestern Nigeria, northeastern kingdom of Borno, the Benin kingdom in southwest, the Hausa city-state/kingdoms of Katsina, Kano, Zaria, and Gobir in northern-central Nigeria, There were well developed trading networks within these societies from northwards across the Sahara. Most if not all of these kingdoms were conquered and historically decimated. The post developmental debates suggest the colonial under -representation of the periphery societies such as Nigeria. This is relevant to the theoretical undertakings in many areas of post-colonial studies. In development studies, for example, there has been scant quantitative data on the effects of colonial exploitation on the colonies.

Onwubiko (1987) recounts that it has been estimated that between 1450 and 1850 ten million Negro slaves were exported to North America and the West Indies. More critical is the outright plunder and looting of resources from the colonies .In a recent report, Indian government in 2013 made an entreaty to Prime Minister Donald Cameron for a return of the looted105 Carat Koh-i-Noor diamond also the classical Elgin Marbles of Greece that Athens have been demanding be given back to them(Amadi and Ekekwe,2014).

Similarly, both the Lagos and Benin conquest in southwest Nigeria had similar fate as the British officials looted the elephant tusks and ivory. Studies and research on colonial onslaught on the colonies such as economic exploitation and impoverishment are poorly funded. Mainstream normative ethical theories generate post development ethics which is important in development studies (Gasper, 2004). The colonial maps and geographical asymmetry of Nigeria invented by the colonial state have been problems at arriving at several national policy decisions in Nigeria. The false colonial maps made the north seem outrageously larger than the south ,there is dichotomy and subsequent division of the country along geo political lines which furthered novel division of Nigeria(see James Coleman,1959), including the ethnic minority question which has been at issue since 1958 resulting contemporary militant insurgency in the Niger Delta. A remarkable feature of the contradictory implication of colonial rule in Nigeria is the identity question. The false colonial identity at the invention of (Niger-area) Nigeria is replete with contentions and contradictions. In 1914, the politically, culturally, educational and religiously different Northern and Southern Protectorates were amalgamated and the entity called Nigeria emerged. 
A resurgent identity challenge today is discernible in Nigeria as several Nigerians are attached to their ethnic identity rather than the Nigerian (national) identity. The nationalistic identity is in doubt at the time of critical re-assessment of who a Nigerian is. An Efik is first Efik then Nigerian, Esan is Esan then Nigerian, Jukun is first a Jukun before accepting to be identified as a Nigerian. Ibibio is equally Ibibio then Nigerian. There is no common identity factor for a Nigerian other than the national currency, the national pledge and anthem, the national flag and a few insignificant others. Such challenges of non -collective identity breeds sectional rather than national interest. This results to modes of behavior that could repeatedly account for false ethnic consciousness and intolerance that gave rise to such incidence as the 1966 pogrom against the Igbo and subsequently a thirty month civil war. The latent agitations of northern minority areas of the present Middle Belt on their marginalization by the Hausa /Fulani is still alive. Such agitations and marginalization was part of the issues that resulted the scuttled Gideon Okar military coup from the Middle Belt. The widely shared abysmal perception of colonial history of Nigeria is reinforced in leadership failure and concerns about the high visibility of corruption, and the overall context of disillusionment after five decades of post- colonial rule. The strategy propagated and reproduced by the colonial state and employed as a device to administer the colonies was both derogatory, interventionist, dictatorial and oppressive and ironically was inherited by the emergent political elite.

In 1929 the first well-articulated anti- colonial riot was led by women in Aba among whom was the late Magaret Ekpo when the colonial office tried to impose taxation on women. The celebrated Aba women riot has been both historic and indicative of "the poverty of colonial administration". Generational negative commemoration of this trend trails Nigeriae"s colonial history. This may explain why gender inequality has remained a perennial challenge of the post -colonial Nigeria and reappears in the annals of governance and decision making process as women are rarely considered in holding top political offices .Forging a new mode of participatory and inclusive governance has been more fashionable in a nascent democracy, thus a revisited notion of gender equality should be the basis for a common political and socio- economic yardstick for demonstrating and addressing the questions of inequality and inclusive participation of women in governance which was not a substantial part of the agenda of the colonial state. Recommendations There is increasing urgency for Nigeria to rise beyond the derisive ,lopsided and parochial colonial developmentalism. The simple thesis of this paper is: how do Nigerians re-write the bias colonial history, address the complexities and contradiction of the post- colonial state and advance in all development fronts politically, technologically and economically? We argue here that the colonial history of Nigeria is a guess work. The 21 st century ushers in changes and novel identity in the international development as globalization has taken toll in all aspects of human endeavor. Castells(2000) contends that a "new society is emerging". How is Nigeria"s heritage and values preparing her to key in or confront the new society?.China is increasingly advancing despite colonial exploitation and under development,North Korea,Malaysia, Taiwan, Hong Kong in South East Asia are advancing developmentally, is Nigeria following suit?.

Confronting post -colonial contradictions is largely attitudinal and involves value re-orientation and self - reassertion.Development is attitude and perception of oneself and others. How do Nigerians see themselves and how do others see Nigerians?. If the external perception of the Nigerian image is negative how could it be restored?, These are some of the fundamental issues in re-writing the bias colonial history of Nigeria. It starts with discipline, propagation of new nationalism and upholding autochthonous identity. For instance, the colonial name "Nigeria" is the beginning of bias colonial history of Nigeria and wrong identity. Lady Flora Shaw (then Lord Laggard"s girl- friend) casually coined the name ,it does not reflect the true identity of the entity that bears the name, hence poor commitment to the Nigerian cause- values, norms and orientations, nationalism etc. The name Nigeria should be changed through a referendum or similar constitutional means as a matter of policy urgency, identity expediency, post- colonial emancipation, development, decolonization and recolonization of the entity called Nigeria. Name 14 of countries that do not bear true resemblance of the ideals of the people such as the Gold Coast was changed to Ghana, Grain Coast changed to Liberia, Basutholand a former British colony, at independence in 1966 changed to Lesotho, French Somalia changed to Djibouti, Bechuanaland to Botswana at independence in1966, among several others.

Re-moralizing the Nigerian elite is central to development. Development is practical and not an abstraction. It is an ideology that evolves from the people and passion for improved wellbeing that 
should naturally drive the mode of behavior of every Nigerian, it does not thrive with corruption which is a colonial legacy. Nigeria has leadership bankruptcy(Achebe,1983), world leaders such as Mao ,Ghandi, Nyerere had a developmental ideology and radically pursued same. Since 1960, postcolonial Nigeria has no morally emancipated leadership, corruption and elite conspiracy remains at issue (Achebe, 1983). The first republic crashed largely because of corruption resulting in military incursion and a thirty month civil war. The first republic crashed largely because of corruption. Leadership of subsequent republics has not learned any new lessons between 1999to 2014 massive as corruption remained at issue. An ethnically emancipated Nigerian has been a rare phenomenon; a true nationalist leadership is a vacuum in contemporary Nigeria. North Korea developed through nationalist leadership fostered and vigorously pursued by radical development strategy such as the Juche policy, in China the Great Leap Forward was advanced through patriotism and nationalism, similarly the development states of south East Asia emerged through genuine commitment to what Mydal (1968)termed the "development ideology" such as Hong Kong, North Korea, Indonesia, Taiwan, Malaysia etc.

\section{CONCLUSION}

In the past hundred years of "colonial creation of Nigeria" and five decades of political Independence, economic development has been elusive as Nigerian leadership followed the trends laid down by the departing colonialists. A radical departure from post-colonial machination is suggested. Whether from a laudatory or derogatory perspective colonialism has been a major impeding factor to the development of most periphery societies such as Nigeria. This article has attempted to provide a novel incisive analysis of the perennial problems of post colonialism in Nigeria particularly its salient contradictions in the idea of, and struggles to gain and control political power and the oil resources of the nation with poor commitments to overcome colonial exploitation as a teleological interface to underdevelopment in post- colonial Nigeria.

This of course is not a new debate rather the article deployed a new mode of inquiry. It addressed a distinctively colonialism and under-development debate and seeks to repeal the laudatory commemoration of colonialism, on the contrary, explores its increasing contradictions and complexities in the post- colonial Nigerian state. This paper forms an important policy discourse on effecting meaningful changes and reformulation of the colonial "legacies" as instrumentalities of subjugation, economic plunder and under development in the post oil economy. It maintains that Nigeria should collectively fashion out a "home grown development ideology" and pursue same radically.

This paper is part of a larger anti -colonial and anti-imperialist debate that seeks to increasingly draw the attention of the post- colonial Nigerian leadership to the implications and effects of the colonial legacy and possibly efforts to redress figurations of post- colonial exploitation and Western imperialism.

The discussions in this paper point to recolonization and re-moralizing of the post-colonial Nigeria elite whose conspiracy, complacency and compromise have resulted in poverty of thinking, leadership bankruptcy and economic emancipation of Nigeria since flag independence in 1960.The failure of the political elite to genuinely respond to the development needs of the people, through home grown strategies and make rational policy decisions will continue to foster civil unrest, ethnic mistrust, clamor for secession, political in stability and poor economic transformation etc. Most of these have remained the core development failures of post-colonial Nigeria.

A new nationalism, civil society emancipation and novel brand of nation building and patriotism is suggested as discussed. Although major challenge centers on corruption which is the central clog to development of Nigeria as it vitiates development efforts and broadens rich/ poor gap.

The economic structure of Nigeria is also at issue. Nigeria in contemporary times is both a primary producer and economically dependent and underdeveloped polity insulated from the international system (Amadi and Agena,2015). The rural areas are economically emasculated and dissociated from the urban centers. Inclusive -development is integral to economic growth, to achieve this, economic diversification and a shift from the failed oil economy is inevitable.

Globalization has further sequestrated the resurgent home grown technological and economic proclivities as poor nations seem choice less at the emergent Western globalization project. Anti- 
globalists such as Walden Bello had argued on possible de-globalization (Bello,2003). Nigeria is yet to evolve and pursue self- reliant development ideology like the development states of south east Asia. Rather internal problems have largely eroded the strive for development due largely to poor management of the oil resource which is overtly relied on.

Insecurity and terrorism have been a substantial problem in the country since the early 2000s following militancy in the Niger Delta and the insurgent religious fundamentalism Boko Haram which has continued to claim many lives in the northeast Nigeria.

Since the post -colonial era, Western aid has been a substantial strategy available. Theories that premise self -reliant development as broader paraphernalia of transformation and economic liberation is less prioritized. Relying on Western aid may not foster sustainable self-reliant economic development. A change in attitude and novel thinking for patriotic and emancipatory endeavor would best facilitate the development of Nigeria.

Nigeria has no such genuine development ideology. Malaysia in the late 1960s imported palm seedlings from Nigeria, today they are world leaders in oil palm produce while Nigeria's oil boom has turned to oil doom. In Nigeria, it is an irony that a sixth world leader in crude oil production does not have a functional refinery!. The Niger Delta is marginalized, true federalism has been a problem. Julius Nyerere of Tanzania one of the outstanding African leaders pursued Ujamma as a home grown development project. This article suggests alternative home grown participatory development strategy for Nigeria at the post crude oil economy.

The aid based strategies such as Structural Adjustment Programme (SAP) of the mid 1980s failed. Nigeria and Nigerians cannot perpetually remain twisted with the ugly memory and sad commemoration of colonial plunder. Nigerians should rise beyond the woes of colonialism and confront the exploitative international capitalist system . It is true that delinking and re linking from the exploitative international capitalist system by a dependent economy is a challenge Nigeria has no choice than to confront capitalism.

Alternative strategies that are non-dependent on the West are plausible. Nigerian state is riddled with contradictions, for instance internal colonialism has been at issue, the big three namely; Hausa /Fulani, Igbo and Yoruba dominate the political and economic space of Nigeria. Moses Ochonu(2008) explores "colonialism within colonialism" to buttress what he termed the "hausa-caliphate imaginary and the British colonial administration" of the Nigerian Middle Belt.

Since 1960, to sincerely evolve an exact census figure has been at issue. Census figures are inexact, to conduct free, fair and credible elections are difficult if not impossible, election has been a "do or die" affair, marred with rigging. The election results are contested or settled in the law courts, ascribed rather than achieved criteria is a substantial part of the public sector recruitment and political appointments. Contracts are awarded without due process and on the basis of informal relationship. Insecurity has claimed several innocent lives as the faceless Boko Haram insurgency unleash repeated terror on the north east Nigeria.

To confront post -colonial contradictions is to evolve capacity for governance, not zoning of political office but certain yardsticks should be constitutionally set up and whoever meets such criteria from whatever ethnic origin or geographical area should rule. The national Assembly should be a part time political endeavor to check the cost of governance as Nigeria has the highest paid National Assembly members in the world. Again economic diversification is key to self-reliant development (see the example of Indonesia).Nigeria has abundant natural resources other than crude Oil. Tin ,Bauxite, Coal ,Gold, The Cocoa economy in the Western region could be resurrected, the groundnut pyramid could be brought back to life, the oil palm economy in the South East Nigeria could sustain the Nigerian economy.

There is abundant aqua culture potential in the Niger Delta as well as untapped tourism potentials. Several countries rely on tourism as economic drivers. An economic blue print and pro poor macroeconomic policy, radical rethinking of the future of Nigeria is critical. The article proposes a participatory civil society that could be proactive like the 2011 Arab Spring. Conscious efforts should be made at building civil society alliances and networks where the citizens could create common grounds to have a voice in governance and decision making, and participate actively in civic responsibilities such as elections, vote massively for candidates of their choice and insist their votes 
must count. Such radical revolution and awareness will collectively redirect the business of governance where state Governors cart away monthly state allocation.

Mismanagement of the economy since 1960 has made a mockery of governance and has been a primary reason for Nigeria's backwardness. Achebe stated that nothing is wrong with the Nigerian environment rather the trouble with Nigeria is failure of leadership(Achebe,1983) Rather than resilient to neo colonial exploitation Nigerians have been subservient partners and vulnerable to Western capitalist exploitation.

Debt burden has derailed economic liberation and dependence on the West which affects Nigeria's international policy thrust. The BRICS and the recently commenced Development Bank (DB) could provide alternative fiscal direction in the international system against the Breton Woods institutions and their financial hegemony namely; the World Bank and IMF. Nigeria should chart a novel cause in search for development. Specifically discipline sincerity and inclusive participatory bottom top strategies are suggested.

\section{REFERENCES}

Achebe C(1983).The Trouble with Nigeria.Enugu :Fourth Dimension.

Ake C (1996).Democracy and Development in Africa. Brookings Institution. Washington, DC. Amadi L(2012). Africa: Beyond the "new" dependency: A political Economy. African Journal of Political Science and International Relations Vol. 6(8), pp. 191-203.

Amadi Land Agena J (2015).Globalization, Culture Mutation and New identity :Implications for the Igbo Cultural Heritage. African Journal of History and Culture vol.7pp16-27.

Amadi Land Ekekwe E (2014).Corruption and development Administration in Africa: Institutional Approach .African Journal of Political Science and International Relations(AJPSIR)vo 1.8(x )pp xx-Xx Xxxx.

Amadi L, Imoh-Itah and Roger A(2015).Dynamics of Local Conflict in Post 1990 Africa: A Case of Border Dispute.International Affairs and Global Strategy Vol.36,5-18.

Amadi L, Wordu S and .Ogbanga M (2015). Sustainable Development in crisis? A Post Development Perspective Journal of Sustainable Development in Africa.Volume 17, No.1, Clarion University of Pennsylvania, Clarion, Pennsylvania

Amin, S. (1997). Capitalism in the Age of Globalization (London, Zed).

Babu A (1981).African Socialism or Socilist Africa. Zed London

Castells, M. (2000). The Information Age: Economy:, Society, and Culture. 3 vols. 2d Ed. Oxford \& Maiden, MA: Blackwell

Bello W .(2003). "The Future in the Balance "Accetance Speech for Right Livelihood Award.

Swedish Parliament, Stockholm (December 8), Available at www.rightlivelihood.se/spe eches/bello.htm (accessed on February 23, 2015).

Castells, Manuel (2000) Toward a Sociology of the Network Society. American Sociogical Associationpp 693-699

Coleman,J (1959).Nigeria Background to Nationalism,London: Longman

Dos Santos .T.( 1970) The Structure of Dependence The American Economic Review (AER), 60(2), $231-36$

Egwu, S (2003). "Ethnicity and Citizenship rights in the Nigerian Federal State"in: Aaron Gana and Samuel Egwu (ed.) Federalism in Africa Trenton: AfricaWorld Press.

Elaigwu, J (2005). "The Nigerian Question: The Way Forward" p34-49 Daily Trust (Ed) Discharging a Burden: The Nigerian Question Abuja: Daily TrustPublications

Ekeh P(1975). Colonialism and the Two Publics in Africa: A Theoretical Statement Comparative

Studies in Society and History, Vol. 17, No. 1., pp. 91-112.

Ekekwe E (1986).Class and State in Nigeria.London: Longman.

Federal Government of Nigeria (2014).Centenary Speech,Abuja:Government Press.

Ferguson J (2006) .Decomposing Modernity: History and Hierarchy after

Development. Department of Anthropology University of California, Irvine.

Frank A (1970). Latin America: Underdevelopment or Revolution. New York: Monthly Review Press.

Furtado C (1964). Development and Underdevelopment. Berkeley: University of California Press. 
Colonialism and the Post- Colonial Nigeria: Complexities and Contradictions 1960 - 2015 A Post Development Perspective

Mamdani, M(1996). Citizen and Subject, Contemporary Africa and the Legacy of Late Colonialism,Kampala: Fountain Publishers.

Nederveen Pieterse J (2010) .Development Theory: Deconstructions / Reconstructions. London: Sage Publications Ltd. 2nd Edition

Nnoli O.(1978).Ethnic Politics in Nigeria.Enugu : Fourth Dimension

Ochonu M(2008).Colonialism within Colonialism: The Hausa-Caliphate Imaginary and the British Colonial Administration of the Nigerian Middle Belt

African Studies Quarterly | Volume 10, Issues 2 \& 3

Onimode B (1988).A Political Economy of African Crisis.Zed Publishers

Rodney W (1972). How Europe Underdeveloped Africa. Washington DC. Howard University Press

Ryan S,(2002)."The African Holocaust: Should Europe pay reparations to Africa for Colonialism and Slavery?", Vanderbilt Journal of Transnational Law, vol. 35, p. 1319.

Topik S (1998). Dependency Revisited: Saving the Baby from the Bathwater, Latin American Perspectives. 25(6):95-99.

Young C (1994).The African Colonial State in Comparative Perspective. New Haven and London: Yale University Press, Pp. xii, 356 